\section{On the Origin of the Basic Amino} Acids

G. EHRENSVARD, L. REIO and E. SALUSTE

\section{Department of Physiological Chemistry, Wenner-Gren Institute, University of Stockholm, Sweden}

$\mathrm{T}$ he classification of arginine, histidine and lysine as the 'basic' fraction of amino acids does, naturally, not imply any closer metabolic relationship between these substances. In fact, very little is known as to their origin. Som evidence point to ornithine, and consequently arginine, as being derived from ghutamic acid via proline ${ }^{1,2}$. As for histidine and lysine very few hints are given as to the formation of the carbon sceleton of these substances. Recently, however, work with Neurospora mutants show that $a$-amino adipic acid might be one of the members of the precursor chain for the formation of lysine ${ }^{3,4}$.

In this situation, some experiments on amino acid metabolism of yeast may give some points of interest. Feeding a strain of Torulopsis utilis with ammonia and acetic acid, the latter being the only carbon source, the acetate, labelled with $\mathrm{C}^{13}$ in the methyl group and with $\mathrm{C}^{14}$ in the carboxyl, enters the metabolism of the yeast, partly appearing in the protein fraction ${ }^{5}$. The yeast, after 3 hours treatment with the labelled acetate, was killed, fats, lipids, carbohydrates and proteins separated, the latter hydrolyzed and subjected to electrodialysis. Using the method of Kossel 6,7 arginine, histidine and lysine were separated, then, recrystallized as flavianate and picrates and finally isolated as mono-hydrochlorides. By combustion of minor samples of the (chromatographically pure) substances, and by ninhydrine treatment $^{8}$ and hydrolysis with $20 \%$, baryta $\mathrm{CO}_{2}$ - free, a series of $\mathrm{CO}_{2}$-samples, trapped as $\mathrm{BaCO}_{3}$, were obtained, repre-
Table 1.

\begin{tabular}{|c|c|c|}
\hline Carbon atoms from: & $\begin{array}{l}\mathrm{C}^{13} \\
\text { Atom per } \\
\text { cent } \\
\text { excess }\end{array}$ & $\mid \begin{array}{c}\mathrm{C}^{14} \\
\text { Counts } / \mathrm{min} \\
\text { per } 15 \mathrm{mg} \\
\text { of } \mathrm{BaCO}_{3}\end{array}$ \\
\hline $\begin{array}{c}\text { Acetic acid } \\
\text { (substrate) } \\
\mathrm{C}^{\mathrm{CH}}{ }^{\text {Carboxyl }}\end{array}$ & 2.42 & $\begin{array}{c}- \\
9850\end{array}$ \\
\hline $\begin{aligned} \text { Arginine } & C^{\text {total }} \\
& C^{\text {carboxyl }} \\
& C^{\text {guanido- }} \\
\text { calc: }: & C^{\mathbf{2 , 3 , 4 , 5}}\end{aligned}$ & $\begin{array}{l}0.082 \\
0.065 \\
0.027 \\
0.100\end{array}$ & $\begin{array}{l}218 \\
356 \\
353 \\
150\end{array}$ \\
\hline $\begin{aligned} \text { Histidine } & \mathrm{C}^{\text {total }} \\
& \mathrm{C}^{\text {carboxyl }} \\
\text { calc: } & \mathrm{C}^{\mathbf{2}, 3 \text {, ring }}\end{aligned}$ & $\begin{array}{l}0.090 \\
0.172 \\
0.074\end{array}$ & $\begin{array}{r}81 \\
3 \\
97\end{array}$ \\
\hline $\begin{array}{ll}\text { Lysine } & C^{\text {total }} \\
& C^{\text {carboxyl }} \\
\text { calc: }: & C^{\mathbf{2 , 3}, \mathbf{4 , 5 , 6}}\end{array}$ & $\begin{array}{l}0.155 \\
0.024 \\
0.181\end{array}$ & $\begin{array}{r}477 \\
1070 \\
360\end{array}$ \\
\hline
\end{tabular}

senting total carbon, carboxyl carbon and, in the case of arginine, guanido-carbon. Isotope analysis of these samples show the following picture:

In the case of arginine the high $\mathrm{C}^{14}$ and the low $\mathrm{C}^{13}$ content of the carboxyl and the guanido-group is what could be expected, the relatively high turnover-rate of the carboxyl group being already earlier observed $^{9}$. Calculation of the average isotope values of the remaining atoms $\mathrm{C}^{2}, \mathrm{C}^{3}, \mathrm{C}^{4}, \mathrm{C}^{5}$, gives $\mathrm{C}^{13}=0.150$ and $\mathrm{C}^{14}=$ 150. Assuming two atoms of high $\mathrm{C}^{14}$ - and low $\mathrm{C}^{13}$-content (round 300 and 0.06 ) the two remaining carbon atoms should be markedly of the $\mathrm{C}^{13}$-type (round 0.20). Another possibility is one atom containing the main part of $\mathrm{C}^{\mathbf{1 4}}$ (round 600) and the remaining three, emanating from the methyl group of the acetate, having a $\mathrm{C}^{13}$-average of about 0.14 . Incidentally, analysis of the glutamic acid from the same experiment gives the $\mathbf{C}^{14}$-value of 1500 and 840 for the $\gamma$ - and the $\alpha$-carboxyls respectively, the three middle atoms being $\mathrm{C}^{14}$-free and with a $\mathrm{C}^{13}$-content of 0.22 . This means that, actually, if the ornithine 
part of the arginine originates from glutamic acid, the observed values for $C^{2,3,4,5}$ are compatible with the corresponding

pattern of glutamic acid $=$ HOOC -

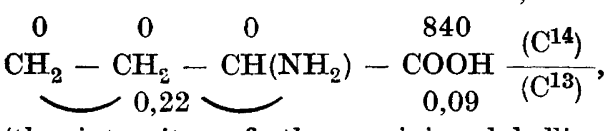

(the intensity of the arginine labelling being round half of that of glutamic acid).

The histidine values, on the other hand, are surprising in view of the absence of $\mathbf{C}^{14}$ in the carboxyl, the high $\mathbf{C}^{13}$-content of which decidedly points towards its origin from the methyl group of the acetate of the substrate, probably through decarboxylation and dehydrogenation of some intermediate $\alpha$-ketoacid structure. Incidentally, during the metabolic breakdown of $a$-ketoglutaric acid to succinic acid, one carboxyl of the latter actually originates from the keto group of the keto - acid, and should thus, in view of the type of labelling of the acetate be of $\mathrm{C}^{13}$-type ${ }^{10}$. Now, it must be taken into account that the other succinic acid carboxyl will be of $\mathbf{C}^{\mathbf{1 4}}$-type and thus the labelling of both carboxyls will be mixed. Considering the pure $\mathbf{C}^{13}$-labelling of the histidine carboxyl, this points to its origin from a $\alpha$-ketoacid structure, the metabolic breakdown of which should form a non-symmetrical carboxylic acid derivative. Decarboxylation and dehydrogenation of the keto-analogue of glutamine, furnishing the half-amide of succinic- or fumaric acid might fit in with this purely speculative view.

Of the non-carboxylic moiety of histidine part of it must have derived from the carboxyl of acetic acid. Assuming the whole $\mathrm{C}^{\mathbf{1 4}}$-content of histidine being located to a single carbon atom of the structure, the $\mathrm{C}^{14}$-value would be about 400 ; if located to two atoms, consequently about 200, the latter being reasonable in view of the low turnover rate of histidine in general.
Remain lysine with an unexpected high

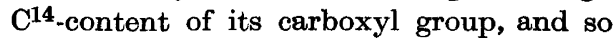
high a $\mathrm{C}^{\mathbf{1 4}}$-content of the non-carboxylic part, that at least two atoms of decidedly $\mathrm{C}^{14}$-type must be located there. In that case each of them might have a $\mathrm{C}^{14}$-value round 900, which is about the same magnitude as the estimated content of the carboxyl $=1070$. In view of the labelling of the latter and the high $\mathrm{C}^{13}-\mathrm{C}^{14}$-overall value for the rest of the molecule $(0.18 /$ 360 ) it seems reasonable to assume that the whole carbon sceleton of lysine has been formed from acetic acid by a direct route, correlated with the head-to-tail condensation of acetyl residues to fatty acids ${ }^{11}$. This view is supported by the fact that the $\mathrm{C}^{14} / \mathrm{C}^{13}$-quotient of fatty acids isolated from the yeast is 0.80 (the isotope quotient of the acetic acid taken as unity), which is about the same as that for lysine $=0.76$. As to the incorporation of the nitrogen atoms during the formation of lysine, the mechanism might involve double bond amination.

The primary data given above show that, at least in yeast, the formation of the basic amino acids must pass over quite different metabolic pathways. In order to make a total check-up of the isotope content of all separate atoms of the amino acids in question, the above simple degradation procedures have to be extended to a total, stepwise break-down of the compounds. Methods with this end in view are by now worked out, and it is hoped to publish the final results gained in the near future.

I. Stetten, M. R., and Schoenheimer, R. J. Biol. Chem. 153 (1944) 113.

2. Shemin, D., and Rittenberg, D. J. Biol. Chem. 158 (1945) 74.

3. Mitchell, H. K., and Houlahan, M. B. J. Biol. Chem. 174 (1948) 883.

4. Geiger, E., and Dunn, H. J. J. Biol. Chem. 178 (1949) 877.

5. Baddiley, J., Ehrensvärd, G., Johansson, R., Reio, L., Saluste, E., and Stjernholm R. J. Biol. Chem. (1949) In press. 